The fern, which was new to me, according to Lady Barkly, may be a form of Polypodium (Grammitis) australe.

In the following particulars I am sorry to have occasion to report failure.

The moss-eating Lepidopterous larvæ all died before our arrival at the Cape.

All the larger Algæ collected were spoilt. One suite of dried examples was lost, through the box in which they were contained being placed open, in the rain, by one of the servants a few days before we sailed, without my knowing it had been moved from its place. The second set, gathered the day before we left the island, was sent on board the 'Supply,' with directions that the box should be placed in an accessible position : unfortunately the message miscarried, the box was stowed away in the hold, and I could not get at it until a fortnight afterwards, when almost the whole of its contents were completely decomposed.

Again, series of examples of some of the flowering plants were lost through the difficulty of attending to them when collected.

I left Kerguelen's Island in H.M.S. 'Supply' on the 27th February, arrived at Simon's Bay on the 31st March, and at Gravesend on the evening of the 7th May. In the course of the yoyage I collected a few animals and Algæ with the towing-net.

\title{
MISCELLANEOUS.
}

On Hemisepius, a new Genus of the Family Sepiidæ, with some Remarks on the Species of the Genus Sepia in general. By M. J. Steenstrop.

Is the memoir of which this is a summary I give, first, a short sketch of the history of the genus Sepia from the time of Linné, remarking that this genuis, as limited by Lamarck in 1798, has since preserved the same signification, although the number of its species has been much augmented: instead of two species only, which it comprised in the time of Lamarck, it now includes more than thirty, of which a third, it is true, are only known by their test (sepium).

The Sepice are rightly considered littoral animals; and we find them on the coasts of nearly every sea, although the two coasts of America have hitherto furnished very few species. Thinking that I could establish that the littoral species of the Cephalopoda have not generally an extensive geographical distribution, or at least not so extensive as the oceanic or pelagic forms, I have naturally been led to suppose that the genus Sepia ought to include a considerable number of unknown species, and I indicate some new ones in my memoir; but beyond new species it ought no doubt to have also other forms still more modified, which might be placed by the side of the genus Sepia as distinct genera; and of this I give evidence in this memoir, the principal object of which is to make known to 
zoologists a little sepian which Captain Andrea has brought me from Table Bay, at the Cape of Good Hope, and which I now publish as a distinct genus, under the name of Hemisepius typicus. Bearing in mind, on the one hand, the common characters which all known species of Sepice present, as well as the modifications that these characters often undergo according to the species, and, on the other hand, the differences due to sex, age, and season, that a long study of the Cephalopoda* has enabled me to demonstrate in individuals of the same species, I establish provisionally, until the discovery of new forms, the three following characters for my Hemisepius, considered as a genus.

Hemisepius, which in other respects completely resembles a Sepia, has (1) a mantle which bears on its ventral surface deep pores, which in the H. typicus are disposed in two rows of twelve pores each, one on each side; these pores are situated in little nipples, and united with one another by a little longitudinal groove; (2) a test which is only half-developed (whence its name); the very rudimentary calcareous partitions do not cover the anterior portion of the dorsal plate, and their anterior margin is not parallel to the corresponding margin of that excessively thin plate; (3) on the eight arms only two rows of suckers, which differ besides from those of the true Sepice by their much depressed and nearly discoidal form. Even without the presence of the pores on the lower surface of the mantle, either of the two latter characters, if we consider the generality of the known species of the genus Sepia, would have sufficed to induce the establishment of a new genus; but as similar pores, so far as I know, are only found in the genus Sepioidea, and are there accompanied by characters which render its separation from the genus s'epiola quite natural, I have thought that I ought to attach all the more importance to their appearance in Hemisepius.

The individual put at my disposal being small (it only measures 53 millimetres long), it was important to get rid of any idea that the animal in growing might lose the characters which distinguish it from all the known Sepice, as to the feeble development of its test and the peculiar form of its suckers \&c. I therefore show that this individual, which is a female and would perhaps have grown larger, may be regarded as adult. In fact, not only is it fit for reproduction, but it has already received spermatophores in the very peculiar situation where they are fixed on all the Sepice, the Sepioteuthes, and the Lotigines, as I showed for these three genera, eighteen years ago, in my memoir on the hectocotylized arms of the male Cephalopoda in general. I reproduce here the following passage relating to these remarkable characters, which have been far too much neglected up to the present time by the naturalists of some countries :-

"The right of employing, as we have done here, the hectocotylized arm as the check of a natural grouping of the Cephalopoda, resides

* These differences between individuals of the same species have generally passed unrecognized; and from this a deplorable confusion in the determination of the species and genera and even of the families has often resulted. 
in its importance for reproduction in general. It is evident that this peculiar structure, sometimes of one pair of arms, sometimes of another, sometimes to the right, sometimes to the left, sometimes at the summit, sometimes at the base, \&c., must involve many differences in the mode of fixation of the spermatic masses or spermatophores on the females, and (inasmuch as the semen does not seem to be poured upon the eggs by involuntary or mechanical, but by conscious movements) in the manner in which fecundation is effected. What simple reflection tells us on this subject is equally confirmed by observation. The spermatic masses are in reality fixed on very different places and in very different conditions, a thing which I shall explain in another memoir of which I here give only the general conclusion-namely, that the genera Sepia, Sepioteuthis, and Lotigo (consequently all those in which I have found the left ventral arm hectocotylized) fix the spermatic masses on the internal surface of the buccal membrane of the females, which is specially organized for that purpose; whilst in the other Decapoda I have never found the sperm fixed in that place, but in various points of the mantle or of the interior organs, in Ommatostrephes for example, far back in the cavity of the mantle, towards the middle part of the back" *

Lastly, I show in my memoir how the application of these spermatic bodies, on such extraordinary points, is effected in reality, in the families of the Sepians and the Loliginians, by means of figures representing types of the principal groups of the Sepias. One of these figures represents the buccal part of Sepia hierredda, a species closely allied to Sepia officinalis, and which might pass for a type of the Sepias with a very strongly developed test, terminating behind in the form of a beak; another the corresponding part of Sepia inermis, which, as a contrast, furnishes a good type of the Sepias with the test very feebly developed and not produced behind. Lastly, Sepioteuthis sepioidea is the representative of the great group of the Loliginians. In all these cephalopods the spermatic:masses in their cylindrical sacs are always fixed to the internal surface of the buccal membrane. I have found this arrangement in many species of these three genera, with only slight modifications in the different species and different individuals of the same species.

Although these characters are of very great importance in the determination of the sex and age of the Cephalopoda, no very clear idea is generally entertained of them. It has even been denied, of late years, that the male Sepias observed in the aquarium had hectocotylized arms, although it is so easy to prove this conformation of the arms in all male individuals; and after this it is not astonishing that we should have had to wait so long for the recognition of the corresponding character on the buccal membrane of the females, although Sepias exist now in many aquariums.

To the figures just mentioned I have added the representation of

* 'Mémoires de l'Académie Royale Danoise des Sciences'' 5th series, vol. iv. p. 213, with two plates (translated in 'Wiegmann's Archiv' for' 1857 , p. 211, and in Ann. \& Mag. Nat. Hist. ser. 2, vol. xx. p. 81, with two plates). 
the buccal parts of the female of Sepia tuberculata of the Cape, because it presented the following peculiarity: the male had fixed the whole mass of the spermatophores on the external surface of the buccal membrane-a thing which I have never seen in any other Sepia, although I have sometimes observed that a few spermatophores had separated from the others and fixed on the external surface, nay, even near the base of the arms. How far is this arrangement entirely accidental in S. tuberculata? This I cannot decide, as I have examined only one individual; at any rate the observation in question is not without interest relatively to Hemisepius, for in that species the spermatophores are fixed on the part of the lip which usually fulfils this office in the Sepians and the Loliginians; but some are found, nevertheless, on the margin of the lip, and even on the external surface. The preceding will suffice, I think, to show that in the actual state of our knowledge our example of Hemisepius, although small, ought not to be regarded as a young and undeveloped individual, but as an adult.

To facilitate the comparison of the characters of Hemisepius and the Sepias the two plates which accompany this memoir contain many details hitherto unknown. It will be seen, for example, that in the species which seems to me to be the Sepia tuberculata, Lamk., there are eight rows of suckers at the extremity of the eight arms, instead of four or two,- that a new species from Japan (S. Andreana) has the arms of the second pair elongated in an extraordinary manner, doubtless to fulfil some particular function,--and that there are even some Sepias which have the lobes of their buccal membrane provided with suckers, like the greater part of the Loliginians, for example the Sepia aculeata, v. Hass._Comptes Rendus, October 4, 1875, p. 567.

\section{On the Ichthyological Fauna of the Island of St. Paul.}

By M. H. E. Sauvage.

The study of the distribution of living creatures on the surface of the globe has acquired great importance of late years, and more than ever we are now-a-days interested in botanical and zoological geography. It is only by the knowledge of the distribution of organisms that we shall succeed in understanding how the forms are grouped which sometimes give so peculiar a physiognomy to a country - that we shall arrive, no doubt, at a knowledge of the migrations of these creatures, and how they have radiated from their centres of origin.

As may be easily understood, isolated islands possess the greatest interest from this point of view. Their flora and fauna have, in fact, remained what they were from the first; and the variations, if variations have taken place, must have been confined within narrow limits, not exceeding what they may be in the type. Undoubtedly the study of the terrestrial and fluviatile animals is most instructive from this point of view; but that of the marine animals nevertheless possesses great interest.

The island of St. Paul, lost in the Indian Ocean, must possess 


\section{$2 \mathrm{BHL}$ Biodiversity Heritage Library}

Steenstrup, M J. 1876. "On Hemisepius, a new genus of the family Sepiidæ, with some remarks on the species of the genus Sepia in general." The Annals and magazine of natural history; zoology, botany, and geology 17, 91-94. https://doi.org/10.1080/00222937608681903.

View This Item Online: https://www.biodiversitylibrary.org/item/63494

DOI: https://doi.org/10.1080/00222937608681903

Permalink: https://www.biodiversitylibrary.org/partpdf/59529

\section{Holding Institution}

University of Toronto - Gerstein Science Information Centre

\section{Sponsored by}

University of Toronto

\section{Copyright \& Reuse}

Copyright Status: NOT_IN_COPYRIGHT

This document was created from content at the Biodiversity Heritage Library, the world's largest open access digital library for biodiversity literature and archives. Visit BHL at https://www.biodiversitylibrary.org. 